\title{
CCD CBERS AND ASTER DATA IN DASOMETRIC CHARACTERIZATION OF Pinus radiata D. Don (NORTH-WESTERN SPAIN)
}

\author{
Eva Sevillano-Marco 1 , Alfonso Fernández-Manso' ${ }^{1}$, Carmen Quintano², Marcela Poulain ${ }^{3}$
}

(received: February 1, 2011; accepted: September 28, 2012)

\begin{abstract}
AChinese-Brazilian Earth Resources Satellite (CBERS) and an Advanced Spaceborne Thermal Emission and Reflection Radiometer (ASTER) scenes coupled with ancillary georeferenced data and field survey were employed to examine the potential of the remote sensing data in stand basal area, volume and aboveground biomass assessment over large areas of Pinus radiata D. Don plantations in Northwestern Spain. Statistical analysis proved that the near infrared band and the shade fraction image showed significant correlation coefficients with all stand variables considered. Predictive models were accordingly selected and utilized to undertake the spatial distribution of stand variables in radiata stands delimited by the National Forestry Map. The study reinforces the potentiality of remote sensing techniques in a cost-effective assessment of forest systems.
\end{abstract}

Key words: Conifers, remote sensing, biomass.

\section{DADOS CCD CBERS E ASTER NA CARACTERIZAÇÃO DASOMÉTRICA DE Pinus radiata D. Don (NOROESTE ESPANHA)}

RESUMO: Partindo de cenas do Chinese-Brazilian Earth Resources Satellite (CBERS) e Advanced Spaceborne Thermal Emission and Reflection Radiometer (ASTER), acopladas a dados georreferenciados complementares e dados de inventario de campo de parcelas permanentes, determina-se o potencial dos dados de percepção remota para a avaliação de área basimétrica, volume $e$ biomassa aérea em superfícies amplas de plantações de Pinus radiata D. Don numa região do noroeste da Espanha. A banda do infravermelho próximo e a imagem da fração sombreada mostram coeficientes de correlação significativos com as variáveis dasométricas consideradas. Os modelos preditivos lineares e não lineares selecionados permitem realizar a distribuição espacial das variáveis dasométricas nos povoamentos de radiata delimitadas pelo Mapa Florestal Nacional. Este estudo reforça a convicção da utilidade da percepção remota na caracterização de sistemas florestais.

Palavras-chave: Conífera, percepção remota, biomassa.

\section{INTRODUCTION}

There is a need for reliable monitoring of forest biomass, in particular to support requirements related to sustainable forest management and carbon (C) accounting. Forest inventories and remote sensing (RS) are the two principal data sources used to estimate $\mathrm{C}$ stocks and fluxes for large forest regions. In general, among the different terrestrial ecosystems, fast growth species, especially coniferous, are major $\mathrm{C}$ reservoirs (LACLAU, 2003).

On the whole, the specific objectives of the present work are 1) to analyse the significance of possible relationships between field-measured forest variables (basal area, stem volume, stem biomass and aboveground tree biomass -within the $\mathrm{C}$ storage) and the visible to shortwave infrared Chinese-Brazilian Earth Resources Satellite (CBERS) and Advanced Spaceborne Thermal Emission and Reflection Radiometer (ASTER) data in Pinus radiata D. Don stands located in El Bierzo (Spain); 2) to evaluate the potential of estimation of stand attributes by fitting adequate model equations derived from the satellite data; and 3) accordingly selecting some of them to outline the spatial distribution of the main stand variables from one of the scenes.

\section{MATERIAL AND METHODS}

\subsection{Study area and dataset}

In El Bierzo, located in North-western Spain, climate and decline of agriculture have favoured the establishment of extensive commercial forest plantations. Even if relatively

\footnotetext{
${ }^{1}$ Forest Engineer, Dr. - University León - Agrarian Engineering and Science Department - Av. Astorga, 24400 - Ponferrada, Spain evasevillano@yahoo.es, alfonso.manso@unileon.es

${ }^{2}$ Telecommunication Engineer, Dr. Professor - University of Valladolid - Electronic Technology Department - C/ Francisco Mendizábal, 47014 - Valladolid, Spain - menchu@tele.uva.es

${ }^{3}$ Forest Engineer, PhD in Forestry - University of Münster - Institute of Landscape Ecology - Robert- Koch- Str. 27 , 48149 Münster, Germany - marpoulain@gmail.com
} 
recently introduced in the region, radiata pine currently occupies an area of approximately $150 \mathrm{~km}^{2}$ in the region (Figure 1).

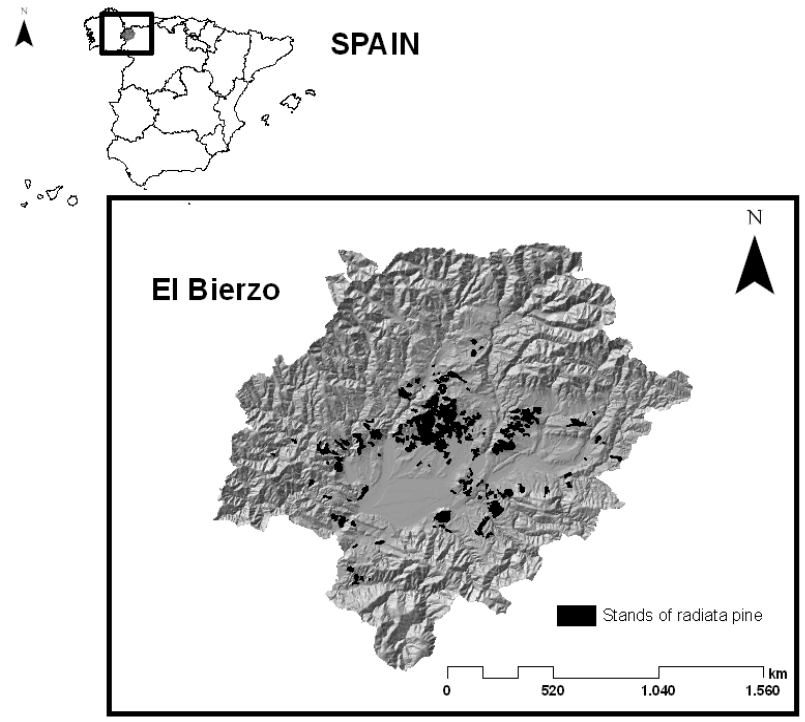

Figure 1 - Stands of Pinus radiata D. Don in El Bierzo (NorthWestern Spain).

Figura 1 - Massas de Pinus radiata D. Don no Bierzo-León (Noroeste Espanha).
To achieve the objectives, three types of data were used: forest inventory, satellite data and ancillary data. Initially, during the early winter of 2003, a network of 45 permanent sample plots was established by the University of León in pure radiata pine plantations of the area of study. The plots, subjectively selected to cover adequately the existing range of ages, stand densities and sites, were rectangular, and sized between 200 and $900 \mathrm{~m}^{2}$ (mean size, $361.4 \mathrm{~m}^{2}$ ), depending on stand density, to achieve a minimum of 50 trees per plot. Limits avoided stand border effects.

Regarding the satellite data, two scenes were used: 1) an ASTER level 1B scene acquired on 14 September 2003; and 2) a CBERS Charge Coupled Detector (CCD) collected on 4 November 2004 (see Table 1).

Concerning the ancillary data, a GIS shapefile (i.e. points layer) was generated from the coordinates of the permanent plot network. Additionally, a total of 15 ground control points were selected from available ortophotographies $(0.25 \mathrm{~m}$ spatial resolution $)$ to adequately verify the geometry and co-registrate the RS scenes to the ground data. Besides, ortophotographies assisted in the definition of the endmember spectra used during the unmixing process of the RS image. In this respect, an extra useful source was a digital terrain model (DTM) (50 m spatial resolution) that assisted the ASTER topographic corrections.

Table 1 - Characteristics of the CBERS CCD and ASTER used bands.

Tabela 1 - Características das bandas usadas do sensores CBERS CCD e ASTER.

\begin{tabular}{lcccc}
\hline Sensor & Subsystem & Notation & Band Name & Lengthwave range $(\mu \mathrm{m})$ \\
\hline & VNIR & $V 1$ & Green & $0.52-0.60$ \\
& (Spatial resolution $15 \mathrm{~m})$ & $V 2$ & Red & $0.63-0.69$ \\
\cline { 2 - 4 } ASTER & $V 3$ & NIR & $0.76-0.86$ \\
\cline { 2 - 4 } & & $S 1$ & & $1.60-1.70$ \\
& SWIR & $S 2$ & & $2.14-2.18$ \\
& (Spatial resolution 30 m) & $S 3$ & & $2.18-2.22$ \\
& & $S 5$ & & $2.23-2.28$ \\
& & $S 6$ & & $2.29-2.36$ \\
CBERS CCD & & $B 1$ & $2.36-2.43$ \\
\hline & VNIR & $B 2$ & Green & $0.45-0.52$ \\
& (Spatial resolution 20 m) & $B 3$ & Red & $0.52-0.59$ \\
& & $B 4$ & NIR & $0.63-0.69$ \\
& & $P$ & Panchromatic & $0.77-0.89$ \\
\hline
\end{tabular}

VNIR=Visible and Near Infrared Radiometer; SWIR=Short Wave Infrared Radiometer; NIR=Near Infrared

Cerne, Lavras, v. 19, n. 1, p. 103-110, jan./mar. 2013 
Finally, from the National Forestry Map (NFM), a polygon layer of radiata stands was extracted, imposing radiata pine as main species (which assures that above $90 \%$ of the stems in the stands are radiata stems). This layer was overlaid to the RS scenes, permanent plots shapefile and ortophotos to contrast spatial resolutions and guarantee consistency of the complete set of georeferenced data.

\subsection{Method}

As Figure 2 displays, there are four main steps in the proposed methodology: field data processing, image processing, statistical analysis, and spatial analysis.

\subsubsection{Field data processing}

The stand variables measured/calculated for each plot were: age $(t)$, site index $(S I)$, number of trees per hectare $(N)$, square mean diameter $\left(d_{g}\right)$ and mean height $(H m)$, stand basal area $(G)$ and volume $(V)$. Total volume estimation implied estimation of total height of the trees not directly measured using the generalized heightdiameter relationship locally developed by SevillanoMarco et al. (2009). The computation of aboveground tree biomass fractions was determined by applying allometric relationships developed by Balboa-Murias et al. (2006) for the species in Galicia using destructive sampling methods. Carbon pools in tree biomass were estimated by fractions as a percentage of the corresponding aboveground dry biomass using the reference found for radiata pine by Ibáñez et al. (2002) which states $49.7 \mathrm{~g} \mathrm{C}$ for every $100 \mathrm{~g}$ of dry wood. Mean, maximum, minimum and standard deviation for each of the main stand variables used in the study are shown in Table 2 .

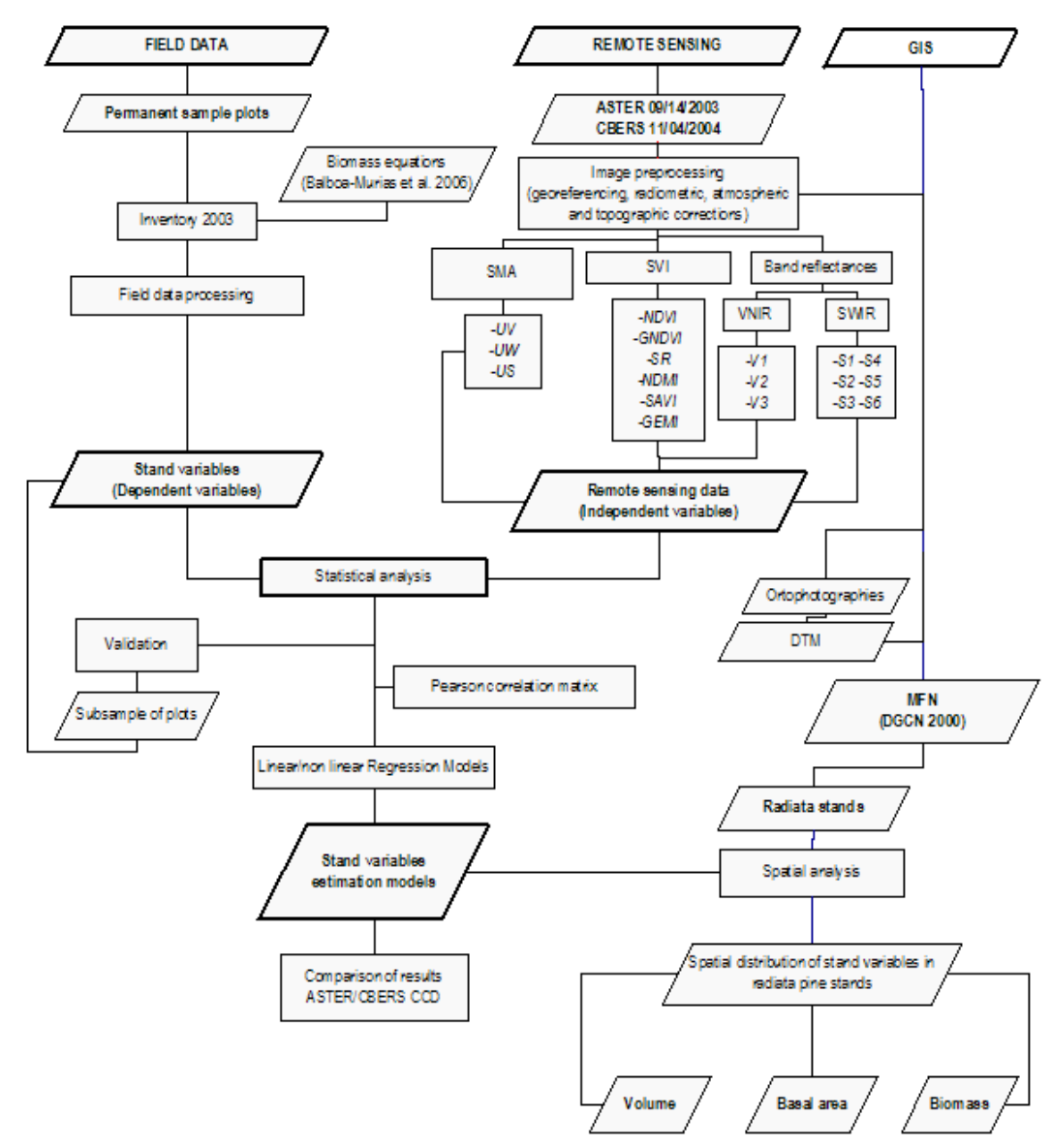

Figure 2 - Methodology flow diagram.

Figura 2 - Diagrama metodológico. 
Table 2 - Summarised field data (used for model development, $\mathrm{n}=40$ plots).

Tabela 2 - Resumo de dados de campo (para ajuste de modelos, $n=40$ parcelas).

\begin{tabular}{|c|c|c|c|c|}
\hline \multirow{2}{*}{ Variable } & \multicolumn{4}{|c|}{ Inventory } \\
\hline & Mean & Maximum & Minimum & SD \\
\hline$t$ (years) & 17.2 & 33.0 & 8.0 & 6.0 \\
\hline SI (m) 20 years base age & 20.7 & 24.3 & 16.9 & 2.0 \\
\hline$N\left(\right.$ stems ha $\left.{ }^{-1}\right)$ & 1726 & 2950 & 400 & 654 \\
\hline$D g(\mathrm{~cm})$ & 16.5 & 29.2 & 7.7 & 4.7 \\
\hline$H m(\mathrm{~m})$ & 15.5 & 24.5 & 5.6 & 4.8 \\
\hline$G\left(\mathrm{~m}^{2} \mathrm{ha}^{-1}\right)$ & 34.2 & 58.9 & 8.1 & 12.6 \\
\hline$V\left(\mathrm{~m}^{3}\right)$ & 9.1 & 33.8 & 0.7 & 6.9 \\
\hline$V h\left(\mathrm{~m}^{3} \mathrm{ha}^{-1}\right)$ & 251.9 & 529.4 & 23.7 & 130.8 \\
\hline$W(\mathrm{Mg})$ & 4.6 & 16.0 & 0.5 & 3.3 \\
\hline$W h\left(\mathrm{Mg} \mathrm{ha}^{-1}\right)$ & 129.7 & 274.6 & 16.6 & 65.7 \\
\hline Ws (Mg) & 3.5 & 13.2 & 0.2 & 2.9 \\
\hline Wsh (Mg ha-1) & 93.7 & 230.6 & 7.4 & 58.6 \\
\hline$C\left(\mathrm{Mg} \mathrm{ha}^{-1}\right)$ & 2.3 & 7.9 & 0.3 & 1.6 \\
\hline Cs $\left(\mathrm{Mg} \mathrm{ha}^{-1}\right)$ & 1.7 & 6.6 & 0.1 & 1.4 \\
\hline
\end{tabular}

$t=$ stand age; $S I=$ site index; $N=$ number of stems per hectare $D g=$ quadratic mean diameter; $H m=$ mean height; $G=$ stand basal area; $V=$ volume; $V h=$ volume per hectare; $W=$ total aboveground biomass; $W h=$ total aboveground biomass per hectare; $W s=$ stem aboveground biomass; $W s h=$ stem aboveground biomass per hectare; $C=$ total carbon stock per hectare; $C s=$ stem carbon stock per hectare; $\mathrm{SD}=$ Standard deviation.

\subsubsection{Image processing and satellite-derived data}

Concerning ASTER data, crosstalk, atmospheric and topographic corrections were performed. The rectification process results in an overall root mean squared error (RMSE) of less than 0.5 pixels. In addition, pansharpening was directly applied to the short wave infrared band in order to merge the scene into one image of $15 \mathrm{~m}$ resolution; and the following Spectral Vegetation Indexes (SVIs) were calculated: Normalized Difference Vegetation Index (NDVI), Green Difference Vegetation Index (GNDVI), Normalized Difference Moisture Index (NDMI) and Simple Ratio (SR) (Table 3).

Regarding the CBERS CCD data, the image was coregistered with the field plots and the rectification process resulted in an overall RMSE of less than one pixel. Linear Spectal Mixture Analysis (LSMA) was applied to the corrected image. We defined three endmembers (soil, vegetation and shade) whose spectral signatures were mainly obtained from the scatter-plot of the original image. In addition to the fraction images (vegetation fraction $U V$-, soil fraction $-U S$-, shade fraction $-U W$-), the following indices were calculated: Global Environmental Monitoring $(G E M I)$, Soil-Adjusted Vegetation Index (SAVI) and NDVI (Table 3).

Finally, an average $3 \times 3$ filter was applied to the original bands, SVIs images and fraction images as a previous step to the extraction of digital values for the field plots surveyed. These values, stored with the information supplied by the field inventory, constitute the complete work data set corresponding to the ASTER and CBERS CCD scenes to be statistically analysed.

\subsubsection{Statistical analyses}

First, a Pearson's correlation matrix was used to verify the existence of relationships between the RS data and the field data. Afterwards, predictive linear and nonlinear regression models (Table 4) were tested for estimation trials, quantifying the relationships between stand variables and reflectances.

As Pearson coefficients do not show but linear relationships between two variables and considering that some models imply more intricate relationships between

Cerne, Lavras, v. 19, n. 1, p. 103-110, jan./mar. 2013 
Table 3 - Spectral Vegetation Indices (SVIs) used for model fitting.

Tabela 3 - Índices de vegetação espectral (IVS) empregados.

\begin{tabular}{lcc}
\hline SVI & \multicolumn{2}{c}{ Formula } \\
\cline { 2 - 3 } $\begin{array}{l}\text { Normalized difference vegetation index } \\
N D V I\end{array}$ & ASTER & CBERS CCD \\
\hline $\begin{array}{l}\text { Green difference vegetation index } \\
\text { GNDVI }\end{array}$ & $G N D V I=\frac{V 3-V 2}{V 3+V 2}$ & \\
\hline $\begin{array}{l}\text { Simple ratio } \\
S R\end{array}$ & $S R=\frac{V 3}{V 2}$ & \\
\hline $\begin{array}{l}\text { Normalized difference moisture index } \\
N D M I\end{array}$ & $N D M I=\frac{V 3-S 1}{V 3+S 1}$ & \\
\hline $\begin{array}{l}\text { Global Environmental Monitoring Index } \\
\text { GEMI }\end{array}$ & & $G E M I=\frac{n(1-0.25 n)-(B 3-0.125)}{(1-B 3)}$ \\
\hline $\begin{array}{l}\text { Soil-Adjusted Vegetation Index } \\
\text { SAVI }\end{array}$ & $n=\frac{2\left(B 4^{2}-B 3^{2}\right)+1.5 B 4+0.5 B 3}{B 4+B 3+0.5}$ \\
\hline
\end{tabular}

Note: The symbols of the formulas of SVI apply to the convention adopted in bands quotation as shown in Table 1. for ASTER and CBERS images bands. Some of the SVIs used are not applicable to both images (see Table 1)

Table 4 - Tested regression models.

Tabela 4 - Modelos de regressão testados.

\begin{tabular}{lcc}
\hline & Base model & References \\
\hline M1 & $y=a x^{b}$ & Heiskanen (2006) \\
M2 & $y=(a+b x)^{2}$ & Padrón and Navarro-Cerrillos (2007) \\
M3 & $y=a \exp ^{b x}$ & Heiskanen (2006) \\
M4 & $y=a+b x+c x^{2}$ & Labrecque et al. (2006) \\
M5 & $y=\left(1+x_{1}\right)^{b} x_{2}{ }^{c} \exp ^{\left(a+d x_{1}+e x_{2}\right)}$ & Muukkonen and Heiskanen (2007) \\
M6 & $y=a+b x_{1}+c x_{2}$ & Freitas et al. (2005) and Labrecque et al. (2006) \\
M7 & $y=a+b x_{1}+c x_{2}+d x_{3}$ & Labrecque et al. (2006) \\
M8 & $y=a+b x$ & Freitas et al. (2005) and Heiskanen (2006) \\
\hline
\end{tabular}

$a, b, c, d$ and $e$ : model parameters, $x$ : independent variable (RS data); $y$ : dependent variable (stand variables)

the dependent variable and more than one independent variable, the model equations were tested taking into account all the possible combinations of independent variables (all bands, fraction images, and vegetation indices) for each dependent variable considered. Comparison of the different models fitted was based on 
numerical analyses and residuals graphical inspection. Three goodness-of-fit statistical criteria obtained from the residuals were examined: coefficient of determination $\left(\mathrm{R}^{2}\right)$, RMSE, and mean percent standard error (S\%) (SEVILLANO-MARCO, 2010).

A subsample of $25 \%$ of the training plots of the field data set was subsequently used for independent validation. The same statistics that served as decision criteria $\left(\mathrm{R}^{2}, \mathrm{RMSE}, \mathrm{S} \%\right)$ were calculated for validating the models that had previously best performed (FREITAS et al., 2005; HEISKANEN, 2006).

\subsubsection{Spatial analysis}

The aforementioned layer of radiata stands generated from the NFM was overlaid to the ASTER image to select the surface occupied by the species to be quantified (which resulted in $69.39 \mathrm{~km}^{2}$ of radiata stands). The values obtained in all the coinciding pixels were accordingly classified and displayed, resulting in layouts of spatial distribution patterns of stand basal area, volume and aboveground stem biomass.

\section{RESULTS AND DISCUSSION}

Firstly, concerning the correlation study, a summary of the highest coefficients of Pearson's correlation is given in Table 5. All the correlations between bands and stand variables are negative for both scenes, which is typical for coniferous stands (EKLUNDH et al., 2003). Positive relationships between stand variables and GEMI and $U W$ have been found. The highest values were obtained with $U W$ and NIR band, followed by GEMI. This result was not surprising: different authors (PEDDLE; JOHNSON, 2000) stated that $U W$ was the best band to estimate biophysical stand variables. Closer relationships between stand variables and RS data were found for $W / C$ and $W s / C s$, followed by $V$.
Secondly, regarding the statistical models and the stand variables estimation, Table 6 shows the linear and nonlinear regression models for stand variables and the statistics of comparison for both scenes, including statistics obtained from the validation subsample.

The model that best fitted for all dependent variables was M5 (MUKKONEN; HEISKANEN, 2007), providing the higher coefficients of determination $\left(\mathrm{R}^{2}\right)$ with but very few exceptions and better behaviour of the rest of statistics (RMSE and S\%).

The outstanding predictive variables were NIR band and $U W$, integrated with other variables in an SVI or as single bands. In general, when considering one single predictive variable, the results were poorer than the ones obtained when combining two or three independent variables. The combinations between bands and vegetation indices showed especially good behaviours. An interesting remark as regards residuals inspection is that, almost in all cases, the model selected tends to overestimate the estimated variable. Overall, the residuals showed an appropriate behaviour, distributed around a mean value of zero.

Thirdly, with regard to validation, correlation coefficients and $\mathrm{R}^{2} \mathrm{val}$ were generally higher for the validation data set. When the regression models were applied to the validation data, RMSEval and S\%val always increased. The comparison of results obtained for both images reinforces the corresponding discussions (SEVILLANO-MARCO, 2010).

Finally, considering the spatial analysis based on the ASTER image, Figure 3 shows the spatial distribution of the estimated stand basal area, volume and aboveground biomass for the whole surface of radiata stands. It can be noted that among the sectors with high biomass, the application of the models provides high estimated values for volume and basal area.

Table 5 - Top Pearson's correlation coefficients ( $n=29$ plots) between dependent variables (stand variables) and independent variables (single bands, vegetation indices and fraction images).

Tabela 5 - Coeficientes de correlação de Pearson mais altos ( $n=29$ parcelas) entre as variáveis dependentes (variáveis dasométricas) e variáveis independentes (bandas discretas, IVs, imagens fracção).

\begin{tabular}{lccccccc}
\hline Image & RS data & $V h$ & $W h$ & $W$ & $W s$ & $W s h$ & $G$ \\
\hline ASTER & $V 3$ & $\mathbf{- 0 , 7 0 2}$ & $\mathbf{- 0 , 6 9 6}$ & $\mathbf{- 0 , 7 2 8}$ & $\mathbf{- 0 , 6 9 6}$ & $\mathbf{- 0 , 6 8 1}$ & $\mathbf{- 0 , 5 9 8}$ \\
\hline \multirow{3}{*}{ CBERS } & $U W$ & $\mathbf{0 , 4 9 3}$ & $\mathbf{0 , 4 8 3}$ & $\mathbf{0 , 5 4 3}$ & $\mathbf{0 , 5 4}$ & $\mathbf{0 , 4 8 5}$ & $\mathbf{0 , 3 0 8}$ \\
& $B 4$ & $\mathbf{- 0 , 4 8 1}$ & $\mathbf{- 0 , 4 7 2}$ & $\mathbf{- 0 , 5 2 4}$ & $\mathbf{- 0 , 5 2 4}$ & $\mathbf{- 0 , 4 7 9}$ & $-0,297$ \\
& $G E M I$ & 0,339 & 0,341 & $\mathbf{0 , 3 3 9}$ & 0,337 & 0,341 & 0,177 \\
\hline
\end{tabular}

Bold: significant at the 0.01 level (2-tailed); Bold and italics: significant at the 0.05 level (2-tailed)

Cerne, Lavras, v. 19, n. 1, p. 103-110, jan./mar. 2013 
Table 6 - Selection of models, dependent and predictive variables, parameters, numerical statistics ( $\mathrm{R}^{2}$, RMSE, S\%) and validation statistics (RMSEval, and S\%val) calculated for data extracted from ASTER and CBERS images.

Tabela 6 - Modelos selecionados, variáveis dependentes e preditivas, parâmetros de ajuste, estatísticas numéricas e de validação (R2, RMSE, S\%, RMSEval, e S\%val) calculados para os dados extraídos das imagens ASTER e CBERS.

\begin{tabular}{|c|c|c|c|c|c|c|}
\hline \multirow[b]{2}{*}{$\mathrm{y}$} & \multicolumn{6}{|c|}{ ASTER image } \\
\hline & \multicolumn{3}{|c|}{$V h$} & \multicolumn{3}{|c|}{$W h$} \\
\hline Model & M5 & \multicolumn{2}{|c|}{ M5 } & M7 & M5 & M5 \\
\hline $\mathrm{a}$ & 15.26 & \multicolumn{2}{|c|}{8.29} & 783762.30 & 16.02 & 9.33 \\
\hline $\mathrm{b}$ & 7.92 & \multicolumn{2}{|c|}{2.66} & -45.71 & 8.90 & 2.94 \\
\hline $\mathrm{c}$ & -12.83 & \multicolumn{2}{|c|}{-21.03} & -159.55 & -15.79 & -25.12 \\
\hline d & -10.61 & \multicolumn{2}{|c|}{-0.31} & -493815 & -11.25 & -0.34 \\
\hline $\mathrm{e}$ & -0.30 & \multicolumn{2}{|c|}{-0.05} & & -0.34 & -0.06 \\
\hline $\mathrm{X}_{1} / \mathrm{X}_{2} / \mathrm{X}_{3}$ & $U W / B 1$ & \multicolumn{2}{|c|}{$B 1 / B 4$} & V3/S6/GNDVI & $U W / B 1$ & $B 1 / B 4$ \\
\hline $\mathrm{R}^{2}$ & 0.441 & \multicolumn{2}{|c|}{0.430} & 0.584 & 0.453 & 0.447 \\
\hline RMSE \pm & 79.5 & \multicolumn{2}{|c|}{80.3} & 42.4 & 39.9 & 40.2 \\
\hline $\mathrm{S} \%$ & 21.1 & \multicolumn{2}{|c|}{21.8} & 25.5 & 19.9 & 20.3 \\
\hline RMSEval & 215.5 & \multicolumn{2}{|c|}{214.2} & 108.6 & 104.2 & 105.7 \\
\hline \multirow[t]{2}{*}{ S\%val } & 62.1 & \multicolumn{2}{|c|}{65.4} & 45 & 62.1 & 66.9 \\
\hline & \multicolumn{6}{|c|}{ CBERS image } \\
\hline $\mathrm{y}$ & $W$ & \multicolumn{3}{|c|}{$W s$} & Wsh & $G$ \\
\hline Model & M5 & M5 & M5 & M5 & M5 & M7 \\
\hline $\mathrm{a}$ & -0.19 & 3.96 & 22.19 & -71.84 & -12.87 & 208.4 \\
\hline $\mathrm{b}$ & 2.89 & 2.31 & -20.45 & -7.59 & 5.77 & -0.05 \\
\hline $\mathrm{c}$ & 0.56 & 0.98 & 55.17 & 28.94 & -0.06 & -210.07 \\
\hline d & -0.02 & -0.02 & -6.59 & 56.74 & -0.03 & 1.82 \\
\hline $\mathrm{e}$ & -4.00 & -6.74 & 0.37 & 0.08 & -0.09 & \\
\hline $\mathrm{X}_{1} / \mathrm{X}_{2} / \mathrm{X}_{3}$ & V3/NDMI & V3/NDMI & $U S / B 1$ & $U S / B 4$ & V3/NDMI & S6/GNDVI/SR \\
\hline $\mathrm{R}^{2}$ & 0.688 & 0.749 & 0.731 & 0.698 & 0.585 & 0.518 \\
\hline RMSE \pm & 1.67 & 1.4 & 1.4 & 19.1 & 42.3 & 8.8 \\
\hline $\mathrm{S} \%$ & 28.0 & 34.8 & 39.9 & 29.5 & 37.0 & 22.8 \\
\hline RMSEval & 6.8 & 6.8 & 58.2 & 45.9 & 88.7 & 19.9 \\
\hline S\%val & 66.8 & 74.2 & 71.7 & 61.4 & 47.7 & 31.5 \\
\hline
\end{tabular}

$G=$ basal area; $V h=$ volume per hectare; $W=$ total aboveground biomass; $W h=$ total aboveground biomass per hectare; $W s=$ stem aboveground biomass; $W s h=$ stem aboveground biomass per hectare; $a, b, c, d$, e are the fitted parameters
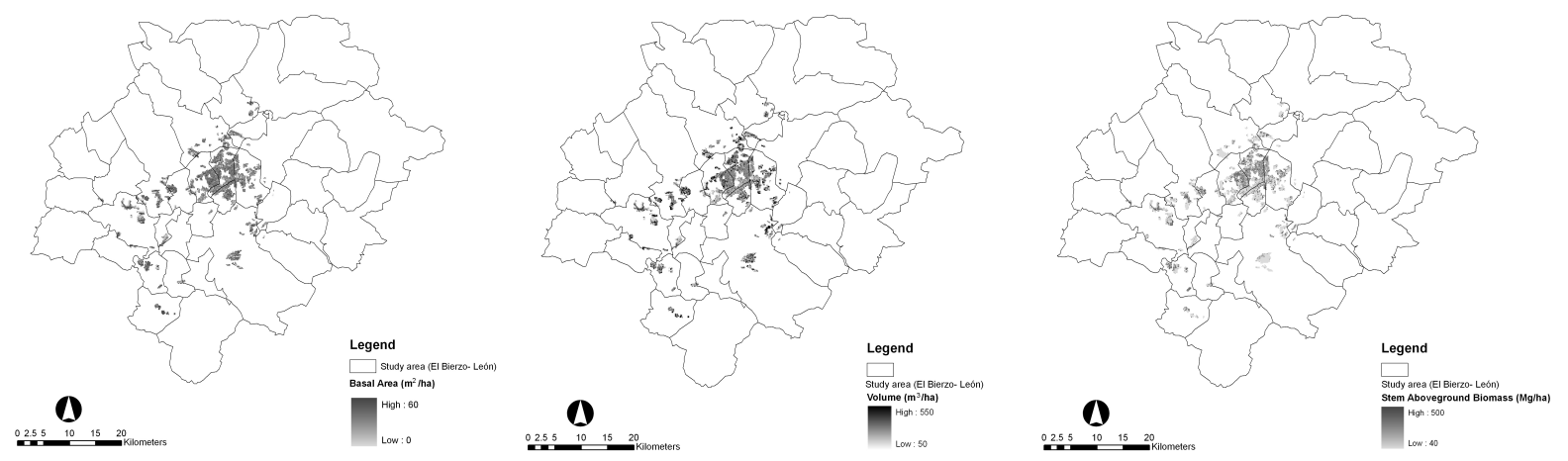

Figure 3 - Left: Estimated stand basal area $\left(\mathrm{m}^{2} \mathrm{ha}^{-1}\right)$, center: Estimated volume $\left(\mathrm{m}^{3} \mathrm{ha}^{-1}\right)$, right: Estimated stem aboveground biomass $\left(\mathrm{Mg} \mathrm{ha}^{-1}\right)$.

Figura 3 - Esquerda: Área basimétrica estimada $\left(m^{2} h a^{-1}\right)$, centro: Volume estimado $\left(m^{3} h a^{-1}\right)$, direita: Biomasa aérea de tronco estimada $\left(M g h a^{-1}\right)$. 


\section{CONCLUSIONS}

This research has investigated the feasibility of new satellite data at medium spatial resolutions, assessing the potential of multispectral images and providing regional evaluation for global scale land cover data sets. The relationships between stand variables and processed remote sensed data has been proved. The results showed that CBERS CCD and ASTER data can be used to estimate biophysical stand variables, in particular $W, W s$, C stocks and $V$. RS allowed obtaining regression models statistically significant that can assist in forest management.

\section{ACKNOWLEDGEMENT}

The authors want to acknowledge the Instituto Nacional de Pesquisas Espaciais (INPE-Brazil) for the distribution of the CBERS CCD image.

\section{REFERENCES}

BALBOA-MURIAS, M. A.; RODRÍGUEZ-SOALLEIRO, R.; MERINO, A.; ÁLVAREZ-GONZÁLEZ, J. G. Temporal variations and distribution of carbon stocks in aboveground biomass of radiata pine and maritime pine pure stands under different silvicultural alternatives. Forest Ecology and Management, Amsterdam, v. 237, p. 29-38, 2006.

EKLUNDH, L.; HALL, K.; ERIKSSON, J.; ARDÖ, J.; PILESJÖ, P. Investigating the use of Landsat thematic mapper data for estimation of forest leaf area index in southern Sweden. Canadian Journal of Remote Sensing, Ottawa, v. 29, p. 349-362, 2003.

FREITAS, S. R.; MELLO, M. C. S.; CRUZ, C. B. M. Relationships between forest structure and vegetation indices in Atlantic Rainforest. Forest Ecology and Management, Amsterdam, v. 218, p. 353-362, 2005.

HEISKANEN, J. Estimating aboveground tree biomass and leaf area index in a mountain birch forest using ASTER satellite data. International Journal of Remote Sensing, Basingstoke, v. 27, n. 6, p. 1135-1158, 2006.

IBÁÑEZ, J. J.; VAYREDA, J.; GRACIA, C. Metodología complementaria al Inventario Forestal Nacional en Catalunya.
In: BRAVO, F.; DEL RÍO, M.; DEL PESO, C. (Ed.). El inventario forestal nacional: elemento clave para la gestión forestal sostenible. Madrid: INIA, 2002. p. 67-77.

LABRECQUE, S.; FOURNIER, R. A.; LUTHER, J. E.; PIERCEY, D. A comparison of four methods to map biomass from Landsat-TM and inventory data in western Newfoundland. Forest Ecology and Management, Amsterdam, v. 226, p. 129-144, 2006.

LACLAU, P. Biomass and carbon sequestration of ponderosa pine plantations and native cypress forests in northwestern Patagonia. Forest Ecology and Management, Amsterdam, v. 180, p. 317-333, 2003.

MUUKKONEN, P.; HEISKANEN, J. Biomass estimation over a large area based on standwise forest inventory data and ASTER and MODIS satellite data: A possibility to verify carbon inventories. Remote Sensing of Environment, New York, v. 107, p. 617-624, 2007.

PADRÓN, E.; NAVARRO-CERRILLOS, R. M. Aboveground biomass in Prosopis pallida (Humb and Bonpl Ex Willd) H. B. K. ecosystems using Landsat 7 ETM+ images. Revista Chilena de Historia Natural, Santiago del Chile, v. 80, p. 43-53, 2007.

PEDDLE, D. R.; JOHNSON, R. L. Spectral mixture analysis of airbone remote sensing imagery for improved prediction of Leaf Area Index in mountainous terrain, Kananoskis Alberta. Canadian Journal of Remote Sensing, Ottawa, v. 26, p. 177-188, 2000.

SEVILLANO-MARCO, E. Dasometric characterization, study of productivity and territorial analysis of radiata pine (Pinus radiata D. Don) in El Bierzo (León). 2010. 177 p. Thesis (Ph.D. in Agroforestry) - Universidad de León, Ponferrada, 2010.

SEVILLANO-MARCO, E.; FERNÁNDEZ-MANSO, A.; CASTEDO-DORADO, F. Development and applications of a growth model for Pinus radiata D. Don plantations in El Bierzo, Spain. Forest Systems, Oxford, v. 18, n. 1, p. 64-80, 2009. 